\title{
Urdimento
}

Revista de Estudos em Artes Cênicas E-ISSN: 2358.6958

\section{Desejo do teatro no político, desejo do político no teatro e político teatro do desejo}

Gisele Vasconcelos

Lauande Aires

\section{Para citar este artigo:}

VASCONCELOS, Gisele; AIRES, Lauande. Desejo do teatro no político, desejo do político no teatro e político teatro do desejo. Urdimento, Florianópolis, v. 3, n. 39, nov./dez. 2020.

DOI: http:/dx.doi.org/10.5965/14145731033920200210 
Desejo do teatro no político, desejo do político no teatro e político teatro do desejo

Gisele Vasconcelos ${ }^{1}$

Lauande Aires $^{2}$

\begin{abstract}
Resumo
O jogo de palavras que mobiliza os termos Teatro, Desejo e Político, propõe uma reflexão no campo da teoria e da prática, do texto e da cena, por meio de três formulações - desejo do teatro no político, desejo do político no teatro e político teatro do desejo - abrindo uma conversa com Guénoun (2003), Rancière (2012) e Benjamin (1994), respectivamente, para pensar os modos de produção e de criação do grupo Xama Teatro (Brasil - MA).
\end{abstract}

Palavras-chaves: Teatro. Desejo. Político. Xama Teatro. Nordeste.

Desire of the theater in the politician, desire of the politician in the theater and politician theater of desire

\begin{abstract}
The game of words that mobilizes the terms Theater, Desire and Politician, proposes a reflection in the field of theory and practice, of the text and scene, through three formulations - desire of the theater in the politician, desire of the politician in the theater and politician. theater of desire - opening a conversation with Guénoun (2003), Rancière (2012) and Benjamin (1994), respectively, to think about the modes of production and creation of the group Xama Teatro (Brasil - MA).
\end{abstract}

Keywords: Theater. Desire. Politician. Xama Theater. Northeast.

El deseo del teatro en lo político, el deseo político en el teatro y el teatro político del deseo

\title{
Resumen
}

El juego de palabras que moviliza los términos Teatro, Deseo y Político, propone una reflexión en el campo de la teoría y la práctica, del texto y de la escena, a través de tres formulaciones: deseo del teatro en lo político, deseo de lo político en el teatro y lo político. teatro del deseo - iniciando una conversación con Guénoun (2003), Rancière (2012) y Benjamin (1994), respectivamente, para reflexionar sobre los modos de producción y creación del grupo Xama Teatro (Brasil - MA).

Palabras clave: Teatro. Deseo. Político. Xama Teatro. Noreste.

${ }^{1}$ Universidade Federal do Rio de Janeiro /PPGAC/UNIRIO (pós-doutorado em andamento). Bolsa FAPEMA. José da Costa (supervisor). Universidade de São Paulo/ECA - doutorado (2016). Professora Adjunta da Universidade Federal do Maranhão - PPGAC. Artista pesquisadora do Grupo Xama Teatro. vasconcelosgisele@yahoo.com.br

2 Universidade Federal do Maranhão/PPGAC (mestrando). Projeto Ator brincante nos Passos do Boi (em andamento). Bolsa CAPES. Gisele Soares de Vasconcelos (orientadora). Ator, diretor e dramaturgo da Cia. Santa Ignorância e do Xama Teatro. lauandeaires@yahoo.com.br 
Desejo é palavra que gera movimento, que agita realidades e subjetividades para a escolha de novos mundos, de novas formas de viver. Das bandas de São Luís do Maranhão, ouvimos e narramos a história do conflito de Catirina, que deseja comer a língua do boi preferido do patrão. Presenciamos o desenrolar deste e de outros enredos criados a partir do fundamento da consumação de um desejo. Na manifestação do Bumba meu Boi, encontramos o mito e o rito inseridos em narrativas que têm como conflito o desejo de possuir o inconcebível: o animal que simboliza tanto a fecundidade quanto o poder. Animal, boi, cujo significado etnográfico determina riqueza e objeto de desejo do dominado.

Esse desejo não diz respeito somente ao de comer a língua do boi, ao de saciar a fome, o sexo, mas trata de uma série de problemas de ordem social, apresentados de forma cômica nos enredos das comédias, matanças e palhaçadas apresentadas no contexto da brincadeira e da festa do Bumba meu Boi $^{3}$ no Maranhão.

Entre narrativas, experiências, subjetividades e metáforas, encontramos no desejo o pressuposto para pensar as interações teatro e política. Como, quando, por que e para quem fazer teatro? Nosso objetivo neste artigo não é conceituar as noções de política, desejo ou teatro e sim pensar como esses termos se articulam e se ordenam em três distintas formas. Onde se encontram as intersecções entre o desejo, o político e o teatro nos modos de criação e produção do Grupo Xama?

Fundado em 2008 e com sede em São José de Ribamar (MA), é um grupo formado predominantemente por mulheres e coordenado por mulheres. Contemplado em projetos importantes como SESC Palco Giratório, SESC Amazônia das Artes, Circulação Petrobrás e outros, o Xama Teatro circulou por todos os estados brasileiros. É um grupo de repertório de oficinas, espetáculos teatrais, narração de histórias e programa de rádio, cuja pesquisa centra-se na

${ }^{3}$ Ver pesquisa sobre o cômico no bumba meu boi (Vasconcelos, 2007). 
arte de narrar, na figura do ator e da atriz-contadora ${ }^{4}$ e da atriz-curandeira.

Considerando a proposta estética e política do Xama, que compreende a junção da experiência, da oralidade e da memória, as montagens teatrais trazem como pontos em comum: a jornada de um herói ou de uma heroína como tema mítico; as histórias pessoais que se mesclam às ficcionais; a busca por sonhos, desejos e anseios; a narração de histórias locais; a mistura de canto, conto e fala na escritura do texto; e a inserção de um dramaturgo engajado no processo criativo da obra. Temas, pessoas e personagens mesclam o particular com o universal, e a fala de um é também a fala de uma multidão. Assim, o desejo da carne de língua (Brenman, 2007), isto é, da alimentação oral, das histórias contadas, orienta o ator e as atrizes contadoras do Xama em sua constante busca por seus sonhos e desejos.

O nome do grupo Xama surge de um sonho - poética do chamado - cujas letras vieram em forma luminosa acompanhadas dos seus significados: Xama de chamar o público; Xama de fogo ardente e criativo; Xama de xamã, nossos ancestrais da sabedoria espiritual e da tradição oral. Com esses três fundamentos: convocação, criação artística e saber da oralidade, abrimos essa roda de conversa para falar sobre a convergência dos termos teatro, desejo e política.

\section{O desejo do teatro no político}

A figura do ator e da atriz-contadora como objeto de estudo das pesquisas do Xama, situa-se em campos limítrofes entre o individual e o coletivo, entre representação e não representação, entre ausência e presença, entre esquecimento e lembrança, o que nos coloca em estado de constante inquietude e transformação de nossos espaços físico, mental e sensível e nos direciona para o ato de ocupar possíveis brechas que surjam no caminho da proposta estéticopolítica do grupo. O desejo de ver o teatro ocupar outros territórios despertou

${ }^{4}$ Ver tese Ator-Contador (Vasconcelos, 2016). 
em nós, artistas do Xama, a inquietude do Desejo do Teatro no Político.

O teatro pressupõe ações como a convocação pública, pois requer pessoas reunidas para a realização de uma apresentação. Para Guénoun (2003, p.14): “A convocação, de forma pública, e a realização de uma reunião, seja qual for o objeto, é um ato político". Assim, esta primeira formulação - a do Desejo do Teatro no Político - independe do que é representado ou apresentado em cena, o que importa aqui é a natureza da reunião, o ato de convocar, de chamar o público e de invocar uma assembleia.

Essa convocação para a rua ou para espaços outros, mantendo o formato que permite que o público se veja, orienta a formulação do Desejo do Teatro no Político, pois como nos diz Guénoun (2003, p.16): "é política a escolha do lugar (afastado ou central, cidade ou vilarejo), da hora (dia, noite, horário de lazer ou de trabalho), bem como da composição e da forma da assembleia". A escolha de ruas, praças, terreiros, salões paroquiais, associações comunitárias como locais para apresentações dos espetáculos do grupo Xama, aliado a escolha do formato cênico que aproxima palco e plateia é uma decisão política.

Figura 1 - Apresentação do espetáculo de rua A Carroça é Nossa

Povoado de Santa Rosa, município de Barreirinhas, MA (2013)

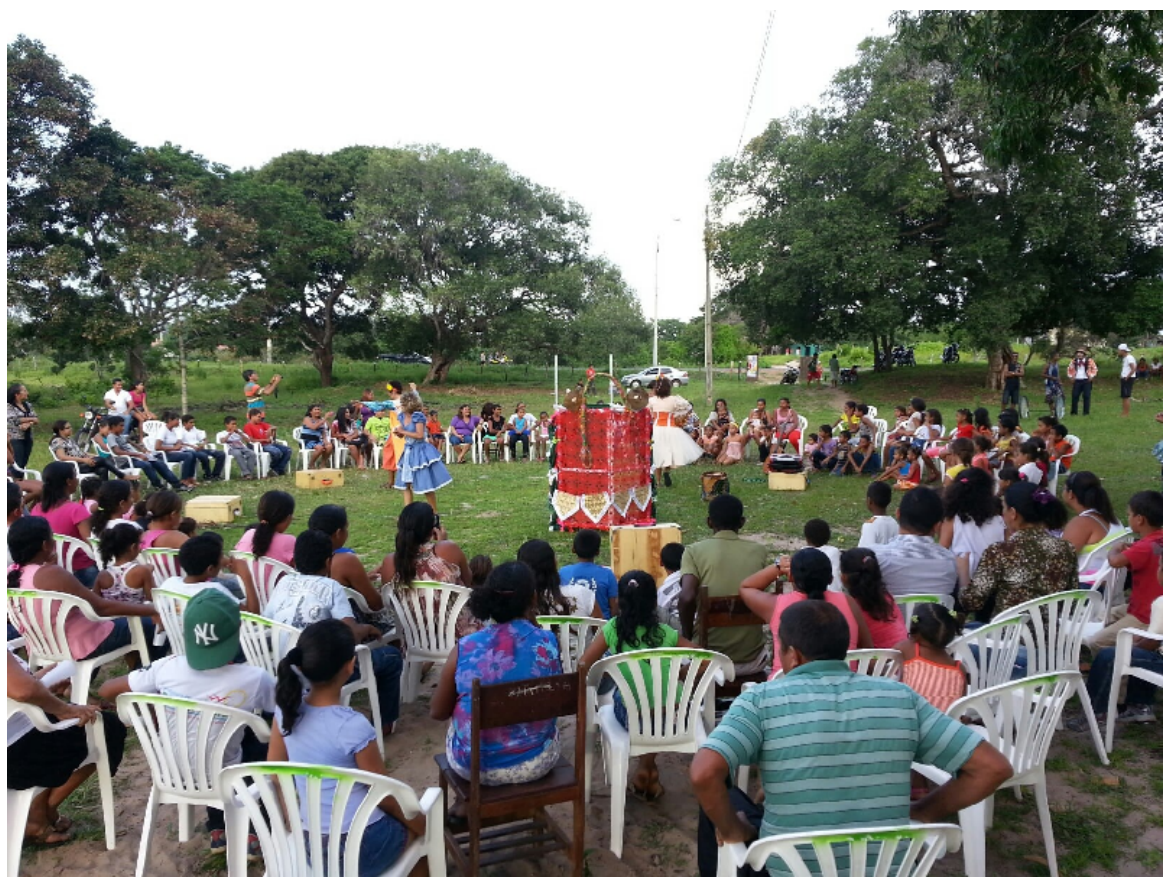

Arquivo do Grupo. Projeto A Carroça na Estrada (Funarte Artes na Rua 2012) 
Uma importante condição para a manifestação do ator e da atriz contadora é a boa disposição do público. Quando as pessoas estão dispostas em formato de roda, que é a proposta do espetáculo $A$ Carroça é Nossa ${ }^{5}$, há uma dinâmica que coloca o público não só na posição de ver e ouvir, mas também permite que esse mesmo público se veja. Os atores e atrizes contadoras na relação direta com a plateia, necessitam vê-la e senti-la. Assim também o público o deseja, quer ver todos os demais, "quer ter o sentimento, concreto, de sua existência coletiva", "experimentar seu pertencimento, sua reunião", e o círculo "é a estrutura que permite que as pessoas se vejam e distingam as demais não como massa, mas como reunião de indivíduos: permite ver os rostos - reconhecer-se." (Guénoun, 2003, p. 20).

Na pesquisa sobre a figura da atriz contadora (Vasconcelos, 2016) chamamos público ouvinte a esse público presente, que se dispõe a ver, ouvir e sentir tanto os atores e as atrizes contadoras que contam, cantam e falam, como todos os demais da plateia. O ator e a atriz contadora exibem na escritura do corpo o elemento invisível dando-o a ver para um espectador que se abre para a escuta: Vem cá! Vem a nós! Vem olhar nossas vozes! ${ }^{6}$ Essa enunciação nos revela, entre tantos desejos, que o teatro quer "mostrar as palavras - que estão, por natureza, no elemento do invisível. O teatro quer exibir o invisível, dá-lo a ver." (Guénoun, 2003, p. 46).

No espetáculo As Três Fiandeiras é ao público que as atrizes contadoras se

${ }^{5}$ O espetáculo A Carroça é Nossa teve origem como criação coletiva, em 2005. O texto atual, escrito em 2012, por Lauande Aires, após oito anos de experimentação com roteiros improvisados, foi organizado a partir das etapas de apresentação das toadas do bumba meu boi, no Maranhão. Nessa obra teatral, quatro personagens, Pedoca (Lauande Aires), Cecé (Renata Figueiredo), Toinha (Gisele Vasconcelos) e Joaninha (Cris Campos), partem em uma jornada em busca do animal para puxar uma carroça "mágica" até os seus sonhos. A Carroça é Nossa é o carro chefe do grupo Xama, e em 2020 completa 15 anos de apresentações ininterruptas e, nesse período, já circulou por todos os estados brasileiros e o distrito federal com participação em importantes projetos como SESC Palco Giratório, SESC Amazônia das Artes, Prêmio Funarte Artes na Rua 2013 e 2015, Circulação Petrobrás Cultural e BASA Cultural.

${ }^{6}$ Licença poética do texto das sereias, descrito na Odisseia: "Vem cá! Vem a nós! Ulisses tão louvado! A honra de Acaia [...]. Pára teu barco: vem escutar nossas vozes! Nunca uma nave negra dobrou nosso cabo sem ouvir as doces melodias que saem de nossos lábios". (Homero, 2006).

Espetáculo autoral do grupo Xama Teatro. Estreou em 2015, recebeu Prêmio Nascente de Artes Cênicas 2015 (USP), tem direção e dramaturgia de Igor Nascimento, e no elenco três atrizes contadoras do grupo, Renata Figueiredo, Gisele Vasconcelos e Rosa Ewerton. Com direção musical e preparação vocal de Gustavo Correia, 
dirigem. Através da poética da voz que narra, elas tornam visível o invisível e materializam, pelo som e pela gestualidade, objetos, pessoas, lugares e imagens. Três atrizes em cena no desafio de transformar o espetáculo que foi um fiasco de bilheteria, decidem remontá-lo misturando suas histórias pessoais com as das personagens da antiga peça e, juntas, narram a história da mãe de Ribamar:

Beatriz - Essa é a história da mãe de Ribamar. Uma mulher que atravessou os sete mares existentes e milhões imaginários para tirar o filho das entranhas do oceano. O menino, pescador, cismou ser. Pouco sabia dos mistérios por detrás das águas. Ignorava a dor descortinada por detrás das lágrimas da pobre mãe que o pariu. Ao saber que o barco de seu filho caçula afundou, Chica se liquides fez. Quase escorria na primeira fresta de chão que encontrasse seu resto de corpo... (As Três Fiandeiras, 2015).

Na relação direta com a plateia que se acomoda sobre assentos que são dispostos nas laterais do espaço de atuação, cria-se o ambiente favorável para que as pessoas se vejam e se reconheçam. As cadeiras são colocadas em um corredor de $3 \mathrm{~m}$ de largura por $5 \mathrm{~m}$ de comprimento, e as atrizes, em As Três Fiandeiras, mesclam papeis ficcionais e reais em um jogo de atuação. Para Guénoun (2003, p. 59-60): “o entrar no jogo da atuação é o vestígio, em cena, do gesto de convite pelo qual o ator foi chamado a subir ao palco. É o começo do teatro, seu princípio, sua produção a partir da cidade. É seu fundamento comunitário, político". 
Figura 2 - Apresentação de As Três Fiandeiras no Projeto Rota de Ribamar, no Colégio IEMA Panaquatira, São José de Ribamar (MA), 2018

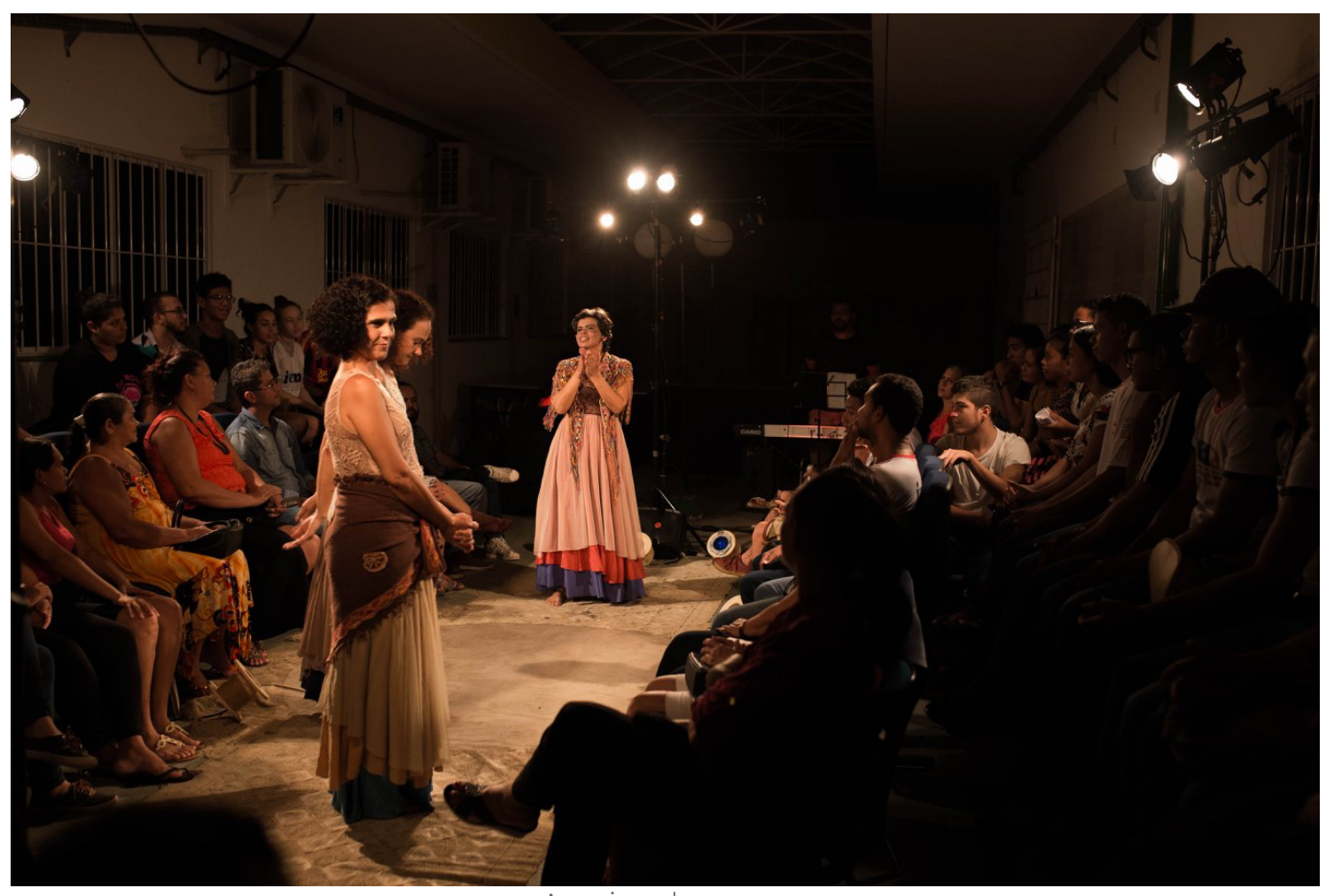

Arquivo do grupo

O desejo do teatro no espaço do político, quando o ator e a atriz são convocados a tomar a voz em cena, funde-se ao desejo de convocar o público para uma apresentação teatral. Esse ato de convocar a plateia possui formatos diferenciados na capital e no interior, na zona urbana e rural. Na comunidade quilombola Santa Rosa dos Pretos, Itapecuru Mirim (MA), durante a circulação do espetáculo A Carroça é Nossa, dentro do projeto Carroça no Rota dos Balaios, nosso trabalho foi divulgado, com cartazes e locução em carro de som que

${ }^{8}$ A Rota dos Balaios, financiada pela Lei Estadual de Cultura com o patrocínio da Psiu e Prêmio Funarte Artes na Rua 2014, teve como objetivo realizar a circulação do espetáculo A Carroça é Nossa seguindo o percurso da Balaiada, no estado do Maranhão. A guerra da Balaiada foi um importante e trágico acontecimento da história de nosso país, ocorrida entre 1838 e 1841, nos estados do Ceará, Piauí e, principalmente, Maranhão. A Balaiada foi liderada pelo negro alforriado Cosme Bento das Chagas, mais conhecido como "Negro Cosme"; o agricultor e fabricante de cestos Francisco dos Anjos Ferreira, "O Balaio" e o vaqueiro Raimundo Gomes, "Cara Preta". No entanto, os louros da vitória ficaram com Luís Alves de Lima e Silva que foi condecorado com o título de Barão de Caxias, patrono do exército brasileiro. O projeto Carroça na Rota dos Balaios, percorreu, no período de julho a outubro de 2015, comunidades localizadas nas cidades de Icatu, Itapecuru Mirim, Vargem Grande, Nina Rodrigues, Chapadinha, Urbano Santos, Anapurus, Brejo, Caxias e São Luís. 
chamavam o público para o "Teatro ao Vivo"9. Mas o teatro não é aquilo que ocorre entre um ator e um espectador, num espaço comum, ao vivo? O público dessa comunidade quilombola, por exemplo, diferenciava o formato ao vivo e não ao vivo, com base na atuação em televisão, única forma de representação dramática acessível por meio da comunicação de massa. Entre as duas formas de representação, a da reprodução industrial que se dá na sala de casa, e aquela que se anuncia ao vivo, da produção artesanal que se dava embaixo de árvores ou terreiros em portas de igrejas, verifica-se o problema do acesso à cultura teatral e a ausência de projetos que insiram novos circuitos artísticos fora do eixo das capitais.

O Maranhão possui 217 municípios com uma concentração de mais de 30 órgãos de cultura presentes exclusivamente na capital, São Luís. A atitude política de preenchimento dos espaços cuja relação de ausência e presença se manifesta, direciona o ator e as atrizes contadoras do grupo Xama Teatro para o encontro das ações de experiência com as comunidades rurais e quilombolas, no Maranhão, em projetos que estabelecem rotas de acesso à produção, fruição e difusão teatral. Destas, podemos destacar a Rota de Maria10 (2009), a Rota dos Balaios (2015), e a Rota de Ribamar11 (2018), com apresentações dos espetáculos A Besta Fera: biografia cênica de Maria Aragão12, A Carroça é Nossa e As Três

\footnotetext{
${ }^{9}$ Nunca fez tanto sentido a voz enérgica do locutor de carro de som e a letra impressa no cartaz: TEATRO AO VIVO. O que antes era incongruente, em 2020, em tempos pandêmicos decorrente da COVID 19, é uma utopia que desejamos que se torne real. Nosso desejo com o teatro de rua se transformou em risco de vida. Nessa distopia, buscamos resistir, ocupar espaços virtuais até que tudo isso amenize e possamos voltar a fazer arte na rua e de rua.

10 Projeto financiado com recursos públicos através do Edital Plano Estadual de Cultura, da Secretaria de Estado da Cultura do Maranhão, para circulação do espetáculo A Besta Fera em 2008: biografia cênica de Maria Aragão, com apresentação em 10 cidades por onde passou a líder comunista e médica maranhense, Maria Aragão (1910-1991), nas décadas de 40 e 50 com a missão de reforçar o Partido Comunista em sua terra natal: Arari, Cururupu, Pinheiro, Caxias, Codó, Itapecuru, Pedreiras, Bacabal, Trizidela do Vale e Paço do Lumiar.

${ }^{11}$ Circulação do espetáculo As Três Fiandeiras com 4 apresentações em 4 comunidades do município de São José de Ribamar, com o apoio da Prefeitura. Atualmente a sede do grupo Xama está situada nesse município, que fica na zona da Grande Itha.

${ }^{12}$ Solo teatral com a atriz Maria Ethel, grupo Xama Teatro, que trata das prisões da líder comunista maranhense Maria Aragão, sua história de pobreza extrema em busca da superação da fome, do preconceito e da agressão. E na perseguição do sonho de libertar a humanidade, através da conquista de uma profissão, a medicina, Maria Aragão entrega-se, apaixonadamente, às causas sociais, lutando por uma sociedade justa e igualitária. Prêmio Funarte Myriam Muniz 2007. Direção: Gisele Vasconcelos. Atriz: Maria Ethel. Texto (org.): Maria Ethel e Gisele Vasconcelos.
} 
Fiandeiras, nas quais incluímos ações de formação e de intercâmbio, como a realização de rodas de conversas com narradores locais. Tais estratégias de rotas são elaboradas a partir das possibilidades de diálogo com as temáticas de cada espetáculo, na tentativa de ocupar espaços de ausências em relação à oferta de serviços e equipamentos culturais, que decorrem da inexistência de uma política pública para a cultura no Estado. As localidades contempladas pelos projetos das rotas são situadas em zonas rurais, longínquas, de territórios remanescentes de quilombos ou em vila de pescadores, em cidades onde ao mesmo tempo em que encontramos a presença da manifestação da cultura fundada na tradição oral, também nos deparamos com a ausência de equipamentos culturais ${ }^{13}$.

É nosso desejo ver o teatro ocupando outros espaços para além dos edifícios teatrais concentrados nas capitais. Entre apresentações dos espetáculos e rodas de conversas com mestres de cada comunidade, professores, produtores culturais, no intuito de ouvir e coletar histórias pessoais e coletivas, ampliando desta forma o repertório oral, narrativo e musical do grupo, buscamos elaborar nossa própria circunferência ao apontar rotas de pertencimento, com criação e desenvolvimento de projetos políticos, propostos por pessoas com uma história de teatro de grupo para uma plateia híbrida em suas necessidades políticas.

Já que o Desejo do Teatro no Político refere-se a ideia de convocação de atores, atrizes e público, reunidos em uma determinada hora e lugar, e define a composição e formatos que exibem o dar a ver o invisível, sem preocupações com o texto e sim com o contexto, o Desejo do Político no Teatro já se preocupa com o que é dito, com o que é apresentado e em como se concretiza e se determinam atitudes, temas, dispositivos, discursos, estéticas do grupo.

\footnotetext{
${ }^{13}$ De acordo com o Sistema de Indicadores e Informações Culturais 2007-2018 (IBGE,2019) a pior situação em relação ao acesso potencial a teatros ou salas de espetáculo encontrava-se no Maranhão com 30,8\%. Em relação aos equipamentos culturais (Cultura em Números, 2010) o Maranhão apresenta a segunda menor média, com apenas 11 teatros, com uma concentração de 72,73\% na capital do estado.
} 


\section{O desejo do político no teatro}

A necessidade de trabalhar poéticas e políticas em cena faz o grupo Xama transitar no terreno da arte política (Rancière, 2012), seja por mostrar os estigmas da dominação; por ridicularizar os ícones reinantes; por sair de seus lugares próprios para transformar-se em prática social; por propor rupturas na distribuição dos espaços; ou porque seus partícipes tomam o tempo que não tem para afirmarem-se coparticipantes de um mundo comum; ou mesmo para mostrar para o público o que não se consegue ver.

Nesse importante processo de pertencimento e para fazer emergir o Desejo do Político do Teatro, o grupo passa a questionar, entre 2010 e 2012, a estrutura dramatúrgica e a encenação de um dos seus primeiros espetáculos, A Carroça é Nossa. Para isso, foi preciso contestar o modelo anterior e investir em um novo formato, novo texto, novas músicas, novo projeto de encenação, novo figurino, maquiagem, instrumentos...

Mas, valendo-nos de uma questão proposta por Rancière (2012, p. 53) perguntamos também: "que modelos de eficácia obedecem nossas expectativas e nossos juízes em matéria de política da arte? A que era esses modelos pertencem?". Tornava-se urgente investir nos modos de criação do grupo, repensar o sentido de comunidade, de pertencimento, no limiar das fronteiras entre arte e vida, o que Rancière (2012, p. 56) chamou de arquiético "como pensamento de uma arte que se tornou forma de vida".

O grupo reafirma a pesquisa da narrativa, de 2012 a 2015, e confirma sua vocação às referências populares ao assumir o diálogo com elementos da cultura maranhense. A mudança radical no dispositivo buscava, em primeira instância, superar as nossas próprias fragilidades, tanto no campo afirmativo do teatro de grupo e suas múltiplas implicações, quanto na nossa relação com a plateia no espaço público. Pretendíamos "ocupar” o espaço público com o mínimo das habilidades presentes nos autênticos artistas de rua, das apresentações populares, dos vendedores de ervas, homens da cobra, enfim, inserir em nossa cena uma verdade aproximada e apropriada ao espaço destinado. 
O texto atual de A Carroça é Nossa, organizado a partir das etapas de apresentação das toadas do bumba meu boi, no Maranhão, foi escrito após oito anos de experimentação com roteiros improvisados. Da oralidade ao texto escrito, o processo de criação de A Carroça é Nossa segue um caminho de experiências compartilhadas pelo ator e pelas atrizes contadoras que partem da tradição e da memória para a criação artística de seus espetáculos. O chão dessa criação é o Maranhão com suas histórias, lendas e ritmos. Na trilha dos narradores anônimos e dos brincantes, daqueles que mobilizam no seu fazer o canto, a dança e a fala, o espetáculo teve origem como criação coletiva, como uma animação, como jogo repleto de oralidades.

Mas importava-nos que o novo texto ultrapassasse o limite das brincadeiras e soubesse costurar suas histórias. E foi assim que chegamos à noção de pertencimento, como nos indica um dos últimos versos do espetáculo:

\footnotetext{
Pertencemos um ao outro Tal como a roda à carroça Tal como o espinho à rosa Tal como a voz à canção Pertencemos um ao outro Tal canutilho e a pena Tal como o sonho à cena Esta é a nossa missão.
}

( A Carroça é Nossa, 2013)

O novo formato do espetáculo culminou na elaboração e aprovação do Projeto Carroça na Rota dos Balaios. Este projeto teve como objetivo circular por territórios por onde ocorreu uma importante revolta popular do Brasil entre 1838 e 1841: a guerra da Balaiada. Em condições de se ver, de se reconhecer, de interagir e dialogar com um espetáculo que, entre versos, conversas e cantorias trata, essencialmente, de sonhos e de pertencimento, o espetáculo A Carroça é Nossa proporcionou uma das mais importantes experiências cênicas para seus envolvidos que arriscaram embrenhar-se pelos emaranhados maranhenses. Apresentamo-nos em cidades de baixo índice de desenvolvimento humano e comunidades distantes até $40 \mathrm{~km}$ da zona urbana do munícipio contemplado, 
por entre areais, riachos e estrada de terra, na busca de um encontro entre o teatro e a política, ou seja, o Desejo do Político no Teatro.

Figura 3 - Comunidade de Vila das Almas, em Brejo (MA). Veículo alugado para transporte de elenco, técnico e cenário para o Projeto de Rotas de Circulação com A Carroça é Nossa

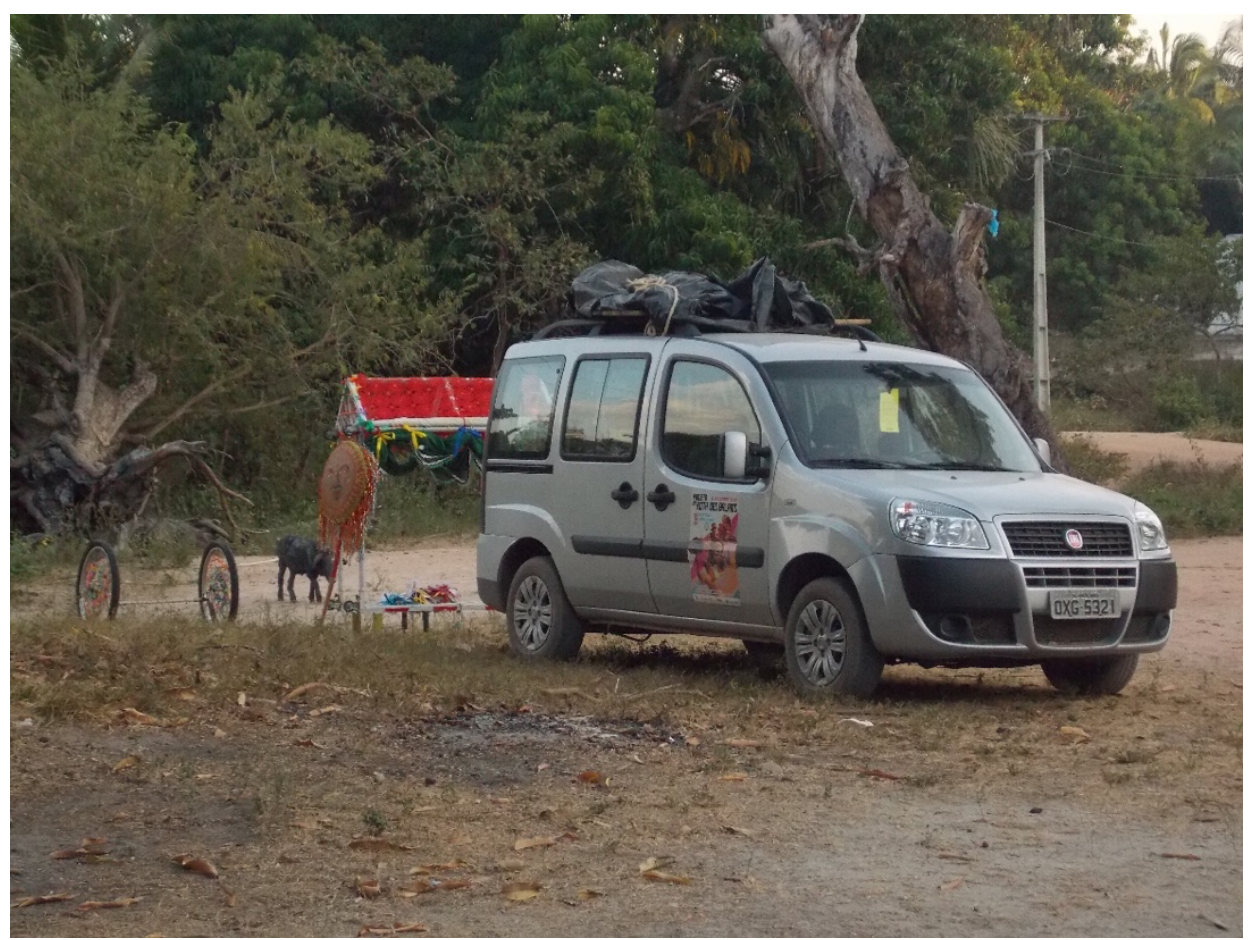

Arquivo do grupo

A oportunidade de apresentar um espetáculo de 80 minutos, com fala, canto e correria, sem o uso de equipamentos de amplificação sonora para público de até 600 participantes, que surgiam do meio do nada, montados em seus cavalos, motos, amontoados em suas caminhonetes e paus de araras, ampliavam o nosso entusiasmo e tornavam-nos uteis por combater, naquele instante, a violenta força da ignorância, do descaso, do desafeto e da cultura de massa, únicas formas de cultura que costumam chegar por tais paragens.

Em certa apresentação na cidade de Brejo, ficamos à disposição da plateia para a sessão de fotos que costumeiramente realizamos após as récitas. Uma senhora e uma menina de cerca de 10 anos se aproximaram. Elas mantiveram certa distância e acompanhavam com os olhos todos os movimentos daqueles 
que pediam para tirar fotografia com o grupo. Demoramos cerca de 30 minutos. Quando não havia mais ninguém a moça se aproximou, empurrou suavemente a menina em nossa direção e perguntou: ela pode dar um abraço em vocês? Ficamos extremamente emocionados ao perceber que a moça não possuía um celular, e aguardou pacientemente "o seu lugar" para intervir, ainda que the tivesse custado meia hora de espera.

Perguntamos: será que as nossas produções teatrais, que tanto reclamam a ausência de um público para teatro, têm se lembrado de um público que os espera, há séculos, ansiosos e de braços abertos?

Figura 4 - Público em foto coletiva após apresentação do espetáculo A Carroça é Nossa, na comunidade quilombola Pequi da Rampa, Vargem Grande, Maranhão.

Projeto Carroça na Rota dos Balaios, 2015

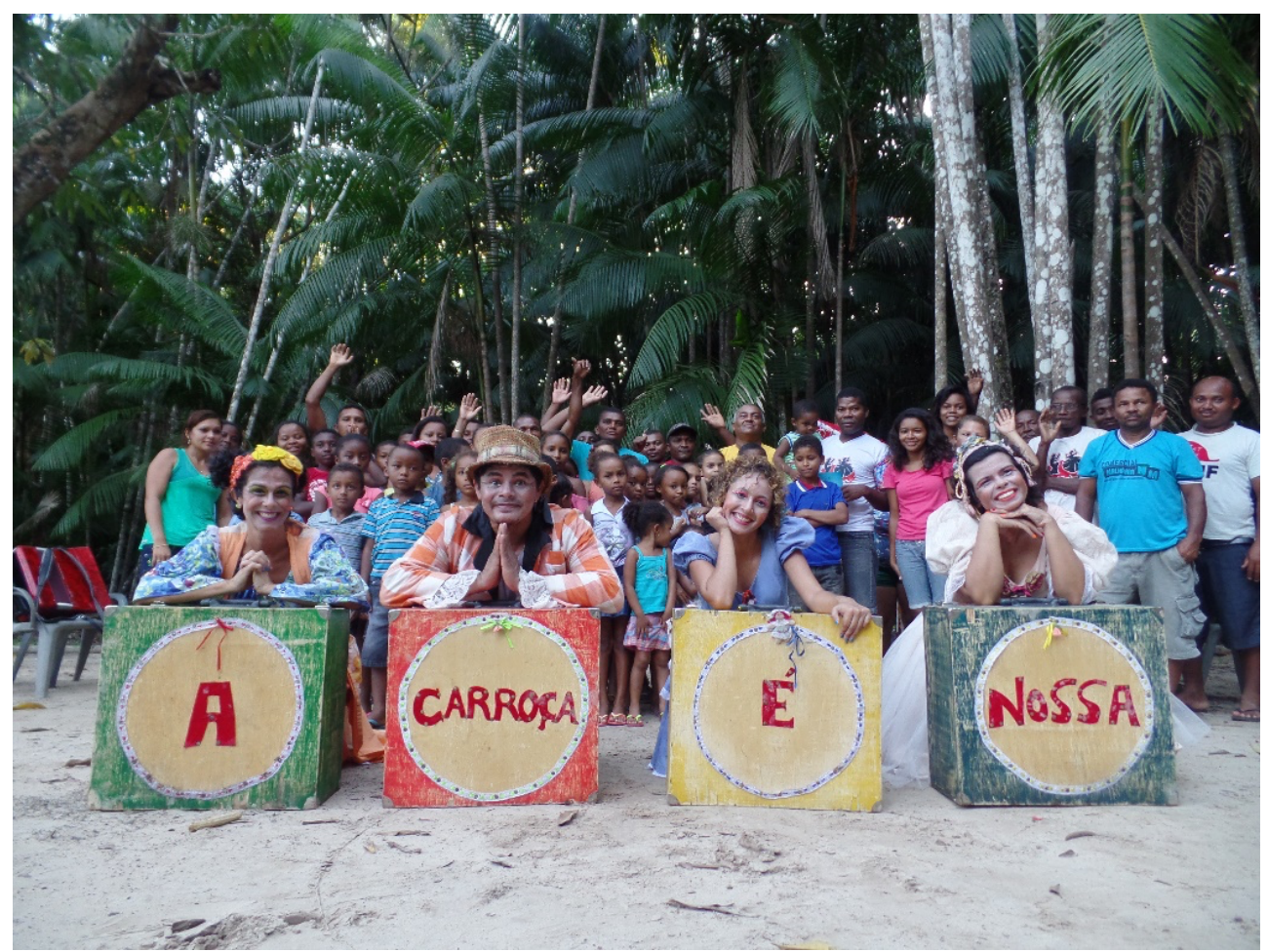

Arquivo do grupo

O político teatro do desejo

Ter realizado apresentações em lugares onde nunca (ou quase nunca) havia 
passado um espetáculo de teatro, para um público ainda virginal nessa experiência, fez com que realizássemos o Desejo do Teatro no Político, o Desejo do Político no Teatro, e nos despertasse para o Político Teatro do Desejo. O texto e o contexto, um discurso posto à prova, em uma simples ação de circulação, reafirma a importância do pertencimento e do saber da oralidade. Nesse espaço que escolhemos para dizer, agora nos sentamos para ouvir ${ }^{14}$.

\section{Figura 5 - Encontro de práticas e de saberes com elenco, produção local e a narradora, mestra de cultura popular, Dona Nazaré, Brejo (MA). Projeto Carroça na Rota dos Balaios, 2015}

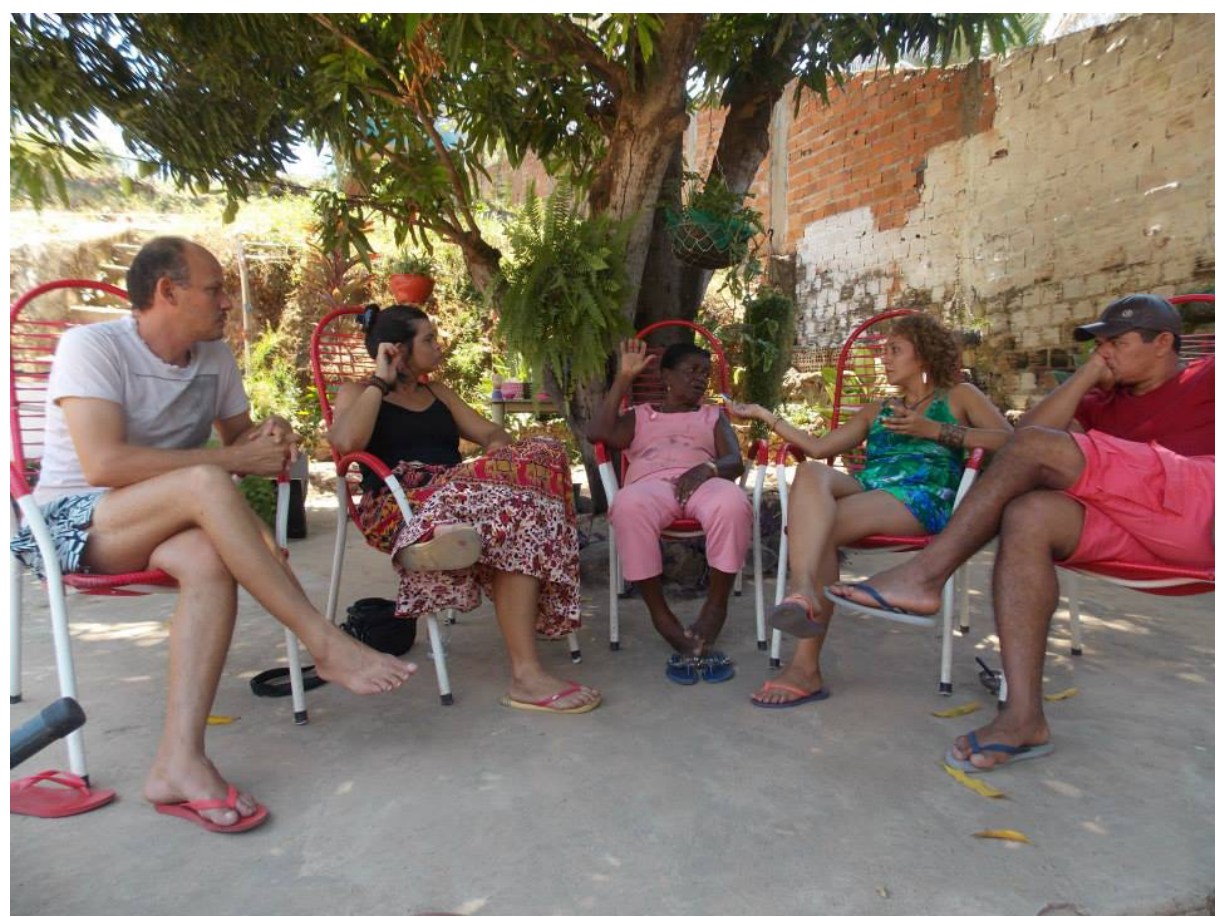

Arquivo do grupo

Com a autoridade da velhice, Dona Nazaré, mestra de manifestações culturais no município de Brejo, Maranhão, nos fala: "Eu agradeço por me fazerem lembrar". No quintal de sua casa, debaixo da mangueira, na presença de seus familiares e de participantes do grupo Xama, ela conta histórias do lugar e histórias pessoais. Entre lendas, contos, episódios reais e inventados ela nos toca

${ }^{14}$ Partes do texto sobre a Rota dos Balaios já foram publicadas, em outros contextos e integra a tese de doutorado: Ator-contador: a voz que canta, fala e conta nos espetáculos do Grupo Xama Teatro. Universidade de São Paulo. 2016. 
com as histórias que revelam traumáticas experiências de humilhação pelo racismo. Suas narrativas transmitidas de boca ressoam em traços sutis de humanidade como retribuição pelo encontro com a arte teatral e pelo interesse da escuta de seu discurso fragmentário, característico dos textos transmitidos pela voz:

O meu pai fala pra nós, que a guerra da Balaiada, começou aqui em Brejo, ele que contava, morreu com 102 anos. Começou por causa de uma família, eles criavam cachorro, e a mulher de um ganhou nenê, e naquele tempo eles matavam o boi e botavam a carne no sol, pra ir comendo durante o resguardo. Aí, o cachorro veio e comeu a metade da carne, aí o outro foi e matou o cachorro do primo, aí o primo foi e matou ele e fol de pai pra filho, e quando o governador veio, a briga já tava na Vila da Manga. Pois é, e aí é assim, nós estamos aqui contando essa história pra vocês que meu pai contava, que o pai dele contava e assim eu conto. Eu não conto direito por que não prestava atenção e quando eu estudava não contavam essas histórias. (Nazaré apud Vasconcelos, 2016, p 34).

Compõem a narração de Dona Nazaré eventos que combinam o real e o fantástico, divergentes dos fatos comprovados registrados pelos historiadores acerca da origem da guerra da Balaiada. Esse discurso que se localiza no tempo infinito da memória reafirma o que disse outrora Benjamin (1994, p. 37): "um acontecimento vivido é finito, ou pelo menos encerrado na esfera do vivido, ao passo que o acontecimento lembrado é sem limites, porque é apenas uma chave para tudo o que veio antes e depois".

Os estudos sobre história e narração reconhecem em Walter Benjamin um referencial em potencial, e seus escritos sobre a figura do narrador e sobre a noção da experiência, enraizada na história dos vencidos, ressoam em nós como eco das vozes dos antigos contadores de histórias. Quando o filósofo alerta para o risco do desaparecimento da arte de intercambiar experiências, de dar e de receber conselhos, ele desenha um retrato da geração de 1914 a 1918, geração que vê os combatentes voltando mudos do campo de batalha da Primeira Guerra Mundial. Nessa formulação, retomamos seus estudos para falar de experiência coletiva, de esquecimento e de lembrança sob a égide da recordação, tal como nos diz:

A recordação estabelece a cadeia da tradição que transmite os 
acontecimentos de geração em geração. Ela é a musa épica em geral e preside todas as variedades do gênero épico. Entre estas, encontramos em primeiro lugar aquela encarnada pelo contador. Ela tece a rede formada por todas as histórias. (Benjamin, 2018, p. 41).

A experiência que se transmite oralmente é a fonte da qual recorrem os contadores de histórias, presentes, segundo Walter Benjamin (2018, p.21) em dois grupos que se interpenetram: o do "camponês sedentário", aquele "que ficou na sua terra, ganhando honestamente sua vida, e conhece suas histórias e tradições", e o do "marinheiro mercador", aquele que vem de longe, que viaja muito e tem sempre o que contar.

Samuel Silva, jovem líder da comunidade Vila das Almas ${ }^{15}$, Brejo, MA, é a voz que fala, em tempos atuais, sobre a voz que silencia em decorrência da pobreza de experiência originária da sangrenta guerra da Balaiada e de outras lutas:

A gente mora aqui, mas não conhece tudo, porque tem muitos deles [os mais velhos] que não querem tocar no assunto, porque é uma lembrança muito doída.

[...] O meu avô não gosta de tocar no assunto é uma história de muito sofrimento que eles não gostam de mexer.

[...] Hoje temos uma área de muito respeito, mas de um sofrimento muito forte. A minha avó, estava de resguardo e morreu no tempo dessa guerra. Eu me sinto elogiado por estar no meio dessa comunidade porque eles eram poucos, mas unidos e capazes de lutar por seu sonho. (Silva apud Vasconcelos, 2016, p. 39).

O silêncio equivalente ao esquecimento se contrapõe à narrativa da lembrança, que junta na experiência da escuta, o ouvir, o ver e o sentir, três processos necessários para fazer a transformação, como nos disse Dona Anacleta, líder do quilombo Santa Rosa dos Pretos, Itapecuru, MA.

A luta da Balaiada, do negro Cosme, continua até hoje em cada um de nós, que compreendemos a história dele, que respeitamos e que sentimos, porque nós temos um processo que é muito difícil, e é por isso que as pessoas, a cada dia que passa, estão se desumanizando. Por que

15 Vila das Almas, no tempo da guerra da Balaiada, era o local de refúgio onde os balaios guardavam suas armas. Antes, o local era conhecido como Saco das Armas e a mobilidade vocal gerou Vila das Almas, onde moram, atualmente, mais de 364 famílias em área quilombola. 
nós, para compreender a história do negro cosme e fazer essa transformação, precisamos ter três processos: um é ouvir, o outro é ver e o outro é sentir. Porque só através do sentimento é que nós somos capazes de ter a sensibilidade e a compreensão de lutar em prol da qualidade de vida. (Anacleta apud Vasconcelos, 2016, p. 39).

A luta permanente dos quilombos do Maranhão pela regularização fundiária, pela garantia dos seus direitos e pela qualidade de vida ressoa na voz dessa liderança e nos remete ao sonho de levar mais humanidade às pessoas por meio do Político Teatro do Desejo. Numa época onde o termo "política" está tão desgastado, é função da arte devolvê-lo ao seu sentido original, ou seja, política: uma atividade pública, comunitária. A arte de conviver, reconhecendo e compreendendo a importância dos três processos: ver, ouvir e sentir.

\section{Referências}

A carroça é nossa. Lauande Aires (dramaturgo), 2013. 22p: Obra teatral (não publicada). Grupo Xama Teatro, Maranhão.

As Três Fiandeiras. Igor Nascimento (dramaturgo), 2015. 55p. Obra teatral (não publicada). Grupo Xama Teatro, Maranhão.

BENJAMIN, Walter. Obras Escolhidas: magia e técnica, arte e política. São Paulo: Brasiliense, 1994.

BENJAMIN, Walter. A Arte de Contar Histórias. São Paulo: Hedra, 2018.

BRENMAN, Ilan. Carne de Língua. IN: As Narrativas Preferidas de um Contador de Histórias. São Paulo: Editora DCL, 2007.

Cultura em números: anuário de estatísticas culturais - 2a edição. Brasília: MinC, 2010. 252p.

GUÉNOUN, Denis. A exibição das palavras. Uma ideia (política) do teatro. Rio de Janeiro: Teatro do Pequeno Gesto, 2003.

HOMERO. Odisseia, canto XII. São Paulo: Cultrix, 2006.

RANCIĖRE, Jacques. Paradoxo da Arte Política. In: O espectador emancipado. Trad. Ivone Benedetti. São Paulo: 2012. 
Sistema de informações e indicadores culturais: 2007-2018. Coordenação de População e Indicadores Sociais. - Rio de Janeiro IBGE, 2019.

VASCONCELOS, Gisele. O Cômico no bumba-meu-boi. 2007. 137p. Dissertação (Mestrado em Ciências Sociais) - Universidade Federal do Maranhão, São Luís, 2007.

VASCONCELOS, Gisele. Ator-contador: a voz que canta, fala e conta nos espetáculos do grupo Xama Teatro. 2016. 205 p. Tese (Doutorado em Artes Cênicas) - Escola de Comunicações e Artes - Universidade de São Paulo, São Paulo, 2016.

Recebido em: 06/05/2020

Aprovado em: 07/11/2020 